\title{
Development and Evaluation of i-Mutawwif: A Mobile Language Traveller Guide in Arabic for Mutawwif (Umrah Tour Guide)
}

\author{
https://doi.org/10.3991/ijim.v12i2.7708 \\ Muhammad Sabri Sahrir $\left.{ }^{\bowtie}\right)$ \\ International Islamic University Malaysia, Kuala Lumpur, Malaysia \\ muhdsabri@iium.edu.my \\ Mohd Firdaus Yahaya \\ Universiti Sultan Zainal Abidin, Kuala Terengganu, Terengganu, Malaysia \\ Taufik Ismail, Muhamad Azhar Zubir, Wan Rusli Wan Ahmad \\ International Islamic University Malaysia, Kuala Lumpur, Malaysia
}

\begin{abstract}
The explosion use of various mobile gadgets such as PC tabs, smartphones, I-Pads and so on has tremendously affected learning process and delivery of content and messages faster and faster including the creation of a new field of research that relates to language learning and mobile technologies called Mobile Assisted Language Learning or MALL. The mobile technologies are suitable for distance learners as well such as traveller's guide and backpackers who need to communicate in certain language in a country. This paper is focusing on the development and evaluation of a mobile language guide application in Arabic language for Mutawwif (Umrah Tour Guide) via smart phones in Android supported platform. The development process was done based needs analysis process among 100 mutawwif and the evaluation on user testing session was conducted among 50 respondents and who are purposively selected from 30 mutawwif and 20 learners in Baitul Mal Professional Institute under the specialization of Diploma in Hajj and Umrah Management from 26 March until 20 April 2017. However, this paper will only be discussing the scope of development and evaluation phases in the shed of ADDIE instructional design model. Overall results indicated that his interactive mobile app prototype satisfied the users' on their language learning for traveller's purpose by helping the Mutawwif to communicate in Arabic more effectively.
\end{abstract}

Keywords-Arabic, mobile learning, distance learning, Mutawwif, mobile gadget.

\section{Introduction}

Mobile learning is found to be providing more flexible learning environment and activities for learners in addition to a traditional and face-to-face instruction. They are 
also suitable for distance learners as well such as traveller's guide and backpackers who need to communicate in certain language in a country. The explosion use of various mobile gadgets such as PC tabs, smartphones, I-Pads and so on has tremendously affected learning process and delivery of content and messages faster and faster including the creation of a new field of research that relates to language learning and mobile technologies called Mobile Assisted Language Learning or MALL as mentioned by Colpaert [1] and Beatty [2]. MALL is defined as "the processes of coming to know and being able to operate successfully in, and across, new and ever changing contexts and learning spaces with an emphasis on understanding and knowing how to utilize our everyday life-worlds as learning spaces" [3]. Hence, the huge use of mobile gadgets such as Tablet PC, smartphones, I-Pads and so on should be adapted by the learners to their learning environment and platform, and it is important for the researchers and educators to ensure that educational practice can include these technologies in productive ways [4].

\section{Problem Statement}

The potential use of mobile devices especially smart phones can be exploited as an attractive and effective learning platform such as promoting active learning [5], merging works, study and leisure time in meaningful ways [6], supporting the effectiveness of mobile technology in a wide range of activities for learners of all ages [7], generating strong positive interests among students [8], [9], and provide convenient learning platform when using the mobile applications and tools in terms of learning flexibility and portability [10]. According to Kukulska-Hulme \& Shield [11], the educators should understand how mobile technologies and devices can be efficiently used to support the effective process teaching and learning. In order to ensure effective use of mobiles devices in an educational setting, there are five features of MALL such as, accessibility, interactivity, immediacy, permanency, situating of instructional activities that should be considered into the account [12].

In addition to that based on Huang, Huang and Lin [13], some merits of mobile technologies such as flexibility, low cost, small size and user-friendliness should also being considered in order to ensure good integration between the mobile devices and learning environment. Although a computer is more excellent than a mobile phone "for handling various types of information such as visual, sound, and textual information, but mobile phone is superior to a computer in portability [14] and its wide access [15]. The flexibility and mobility of mobile learning by using mobile devices are very much related to the tourism and tourists as they are travelling to various parts of the world based on their intended destinations. In recent years, many tourist guidance applications have been developed, such as C-MAP [16], HIPS [17] and PEACH [18]. For practitioners such as Mutawwif (Umrah Tour Guide) who is travelling to Saudi Arabia for performing Hajj and Umrah, they are in need of using Arabic language for various purposes such as communicating, shopping, travelling, and various forms of communications which are difficult for those with no formal learning experience in Arabic language. Hence, this study will be focusing on the development and 
evaluation of a mobile language guide application in Arabic language for Mutawwif (Umrah Tour Guide) via smart phones especially in Android supported platform. The explosion use of various mobile gadgets such as PC tabs, smartphones, I-Pads nowadays is the best mean and way in assisting them in learning Arabic language through a mobile language guide application which provide a flexible, friendly and easy use of mobile language guide application. The study on using mobile learning platform in Arabic was conducted by Mohd Feham et.al. [19] by designing and evaluating a mobile learning portfolio known as 'i-collect' application for Arabic language teaching and learning. The researcher and his team also studied the potential use of mobile learning in Arabic language by designing and evaluating Mobile App Glossary of Terms in Islamic Banking and Finance [20].

\section{Research Questions}

This study embarks on the following research questions:

1. What is the development process for a mobile App of teaching and learning Arabic among Mutawwif (Umrah Tour Guide) based on the needs analysis by the learners and practitioner among Mutawwif?

2. To what extent the practical use and effectiveness of a mobile App of teaching and learning Arabic among Mutawwif (Umrah Tour Guide)?

\section{$4 \quad$ Research Methodology}

This project will be focusing on the development and evaluation of a mobile language guide application in Arabic language for Mutawwif (Umrah Tour Guide) via smart phones especially in Android supported platforms. The design and development process was done based needs analysis process among 100 mutawwif and the evaluation on user testing session was conducted among 50 respondents and who are purposively selected from 30 mutawwif and 20 learners in Baitul Mal Professional Institute under the specialization of Diploma in Hajj and Umrah Management from 26 March until 20 April 2017. However, this paper will only be discussing the scope of development and evaluation phases in the shed of ADDIE instructional design model [21]. The research phases based on ADDIE instructional design model are as shown below:

1. Analysis: Learner's needs among selected Mutawwif, content development and current mobile app.

2. Design: Formulating design theory and storyboard

3. Development: Development tool (web-based tool, HTML + PHP), Playstore registration, uploading and converting, mobile apps package

4. Implementation and Evaluation: User Testing among Mutawwif at Andalusia Travel and Tours and Arabic learners in Baitul Mal Professional Institute under the specialization of Diploma in Hajj and Umrah Management for the prototype. 


\section{Design and Development of i-Mutawwif}

The design and development process of the Mobile Language Traveller Guide in Arabic for Mutawwif (Umrah Tour Guide) via Smart Phones is among the main focus in this paper. The theoretical framework that underlies the design and the practical processes and procedures that contribute to the development is also explained. Table 1 illustrates the design and development framework, which was modified from ADDIE instructional design model.

Table 1. Design and development framework of i-Mutawwif.

\begin{tabular}{l|l}
\hline \multicolumn{1}{c|}{ Phase } & \multicolumn{1}{c}{ Details of Process } \\
\hline Analysis & $\begin{array}{l}\text { Learner's needs among selected Mutawwif, content development and current mobile } \\
\text { app. The needs analysis survey was distributed among 100 respondents of a national } \\
\text { conference of Mutawwif (Umrah Tour Guide) organized at Universiti Sains Islam } \\
\text { Malaysia (USIM), Nilai, Negeri Sembilan, Malaysia on 18 October 2016 (Tuesday). } \\
\text { The administered survey is adapted from Mohd Feham et. al. [22]. }\end{array}$ \\
\hline Design & Formulating design theory and storyboard \\
\hline Development & $\begin{array}{l}\text { Development tool (web-based tool, HTML + PHP), Playstore registration, uploading } \\
\text { and converting, mobile apps package }\end{array}$ \\
\hline $\begin{array}{l}\text { Implementation } \\
\text { and Evaluation }\end{array}$ & $\begin{array}{l}\text { The evaluation survey for the use of this mobile app was distributed among 50 re- } \\
\text { spondents who are purposively selected from 30 mutawwif and 20 learners in Baitul } \\
\text { Mal Professional Institute under the specialization of Diploma in Hajj and Umrah } \\
\text { Management from 26 March until 20 April 2017. }\end{array}$ \\
\hline
\end{tabular}

In general, the design principles of i-Mutawwif in this mobile language traveller guide in Arabic for Mutawwif (umrah tour guide) via smart phones were formulated based on 3 main components which are the need analysis results, and suggestions as well as recommendations by potential users within the limitations of this study.

\section{Development Phases of i-Mutawwif}

The development of i-Mutawwif application is conducted based on the use of hybrid platform for developing mobile application named as Ionic creator. Ionic is a HTML5 hybrid mobile framework built. By using this platform, it helps to build mobile applications fast, easy and beautiful. It also provide to users popular layouts that can be used during the process of development mobile application [23]. The process of mobile app development was conducted such as shown below:

\subsection{Hybrid Mobile Application Development}

The development process of i-Mutawwif mobile application is through hybrid platform. Hybrid platform allows its user to build an application by using their services. Figure 1 shows the process of developing i-Mutawwif application.

Using hybrid platform to develop mobile application such as Ionic Creator has many advantages. Some of these advantages are: 
- Less skill: To develop mobile application, it require less skill and knowledge about coding, furthermore and its steps similar to website development process.

- Cross-Platform: Hybrid platform allows its users to deploy the application on various operating system such as Windows, iOS and Android.

- Quick and easy: There are only few steps to develop mobile application and it allow previewing instantly to smartphone as show at Figure 2. Providing working folders in 'pages' section and drag and drop option in 'components' section in Figure 3 helps users to build mobile application quicker and easy.
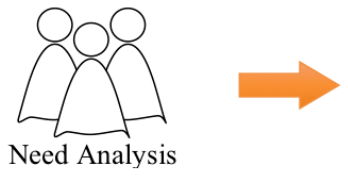

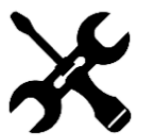

Develop mobile application using Hybrid platform Ionic Creator

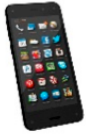

Previewing / Deploy in iOS and Android phones

Fig. 1. Process of developing i-Mutawwif mobile application.

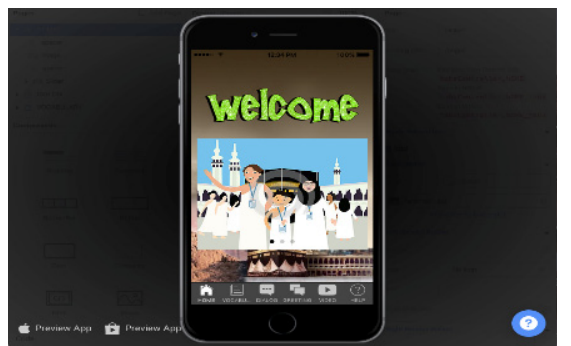

Fig. 2. Page view for "Previewing" section in Ionic creator.

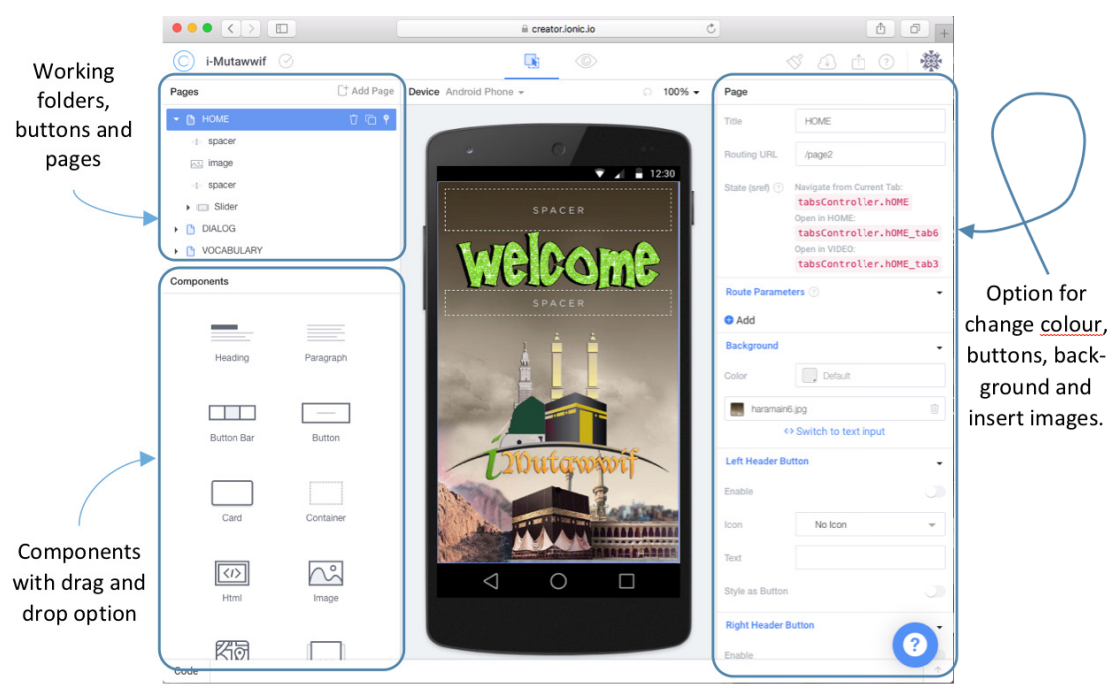

Fig. 3. Page view for "Build" section in Ionic creator. 


\subsection{Development Phases and Processes}

Development of i-Mutawwif mobile application undergo few phases and processes, from design principles, design storyboard, design mobile platform and design iMutawwif. The processes of this development are summarize in Table 2.

Table 2. Development phase and its process to develop i-Mutawwif.

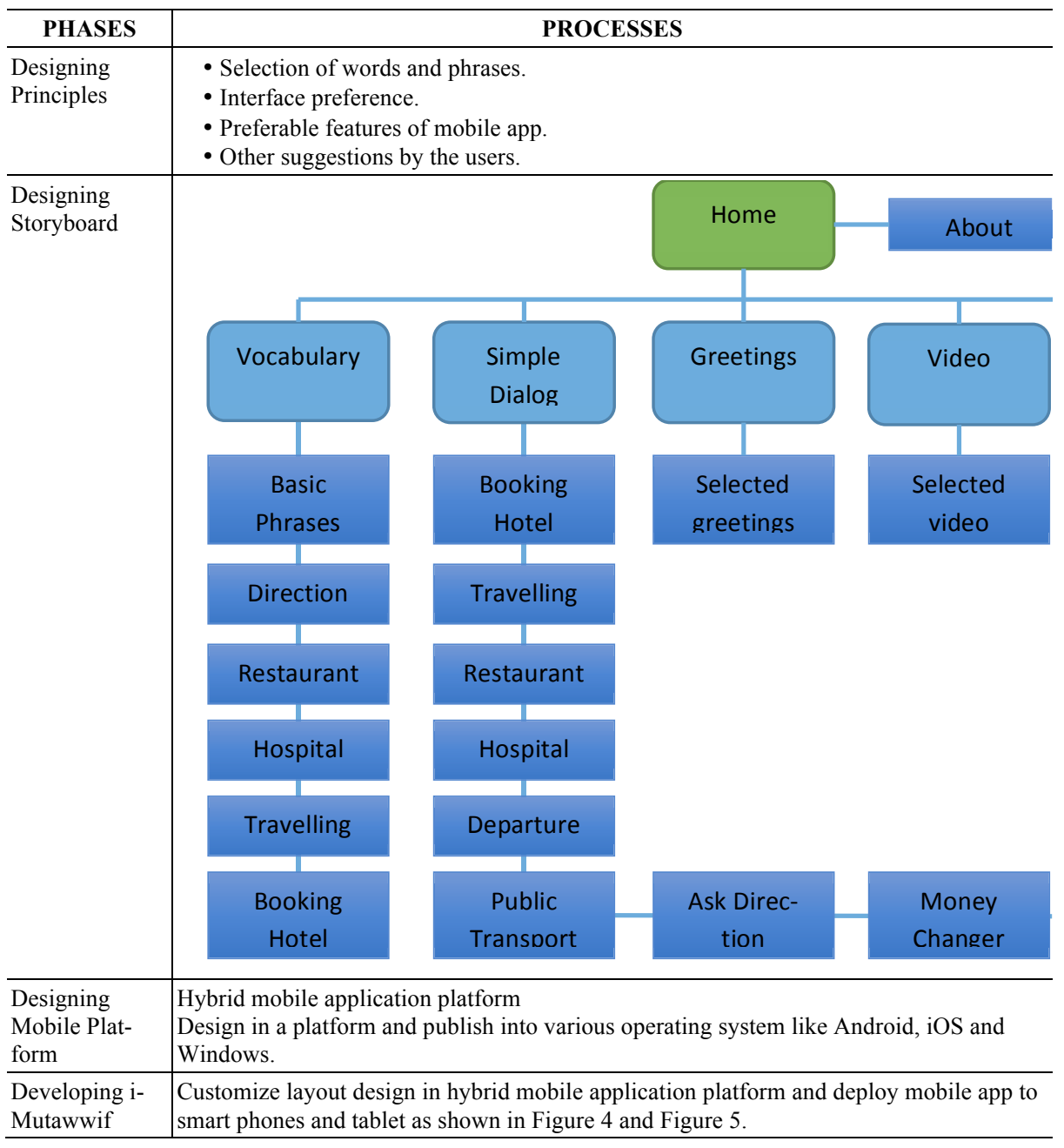




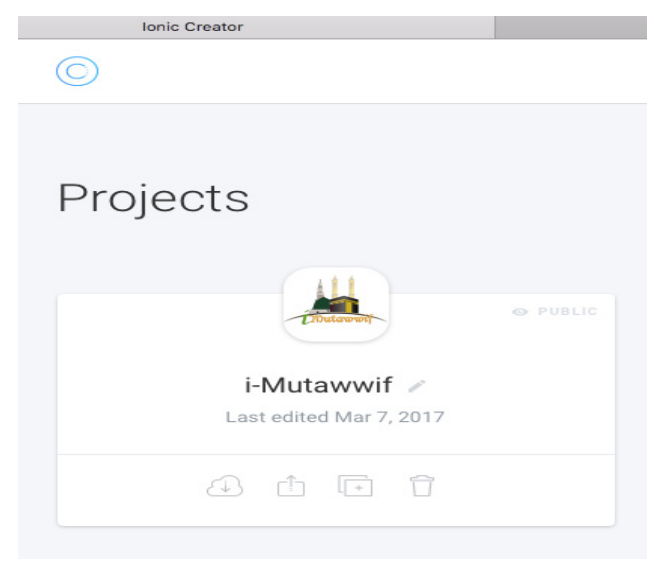

Fig. 4. Ionic Dashboard to build mobile apps.

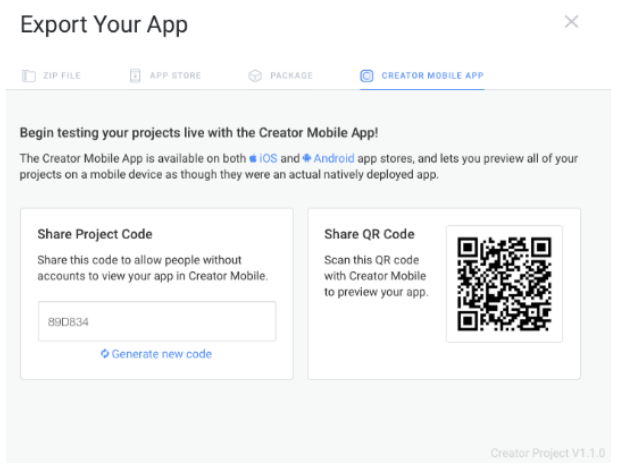

Fig. 5. Export options in Ionic Creator.

By using hybrid platform to develop apps such as Ionic Creator requires fast internet connection and subscription to Ionic creator itself. In addition, it only requires least knowledge of basic web development.

\subsection{Samples of Interface for i-Mutawwif}

The main interface for i-Mutawwif app is as simple as shown in Figure 6. It consist of tabs to navigate the pages inside the app. There are six tabs menu in this app; Home, Vocabulary, Dialog, Greeting, Video and Help. Home tab only shown welcoming page and option for slide pictures. While vocabulary tab consist of basic words in daily conversation during perform Hajj and Umrah. Simple dialogs are also included in this app for basic conversation as shown in Figure 7 and 8. In addition, this app also provides daily basic greetings to its users such as "good morning", "hope to see you again" and "how are you?". While video tab is for future improvement in this application. The last tab is "Help". It consist of several emergency contact numbers in Saudi Arabia. 


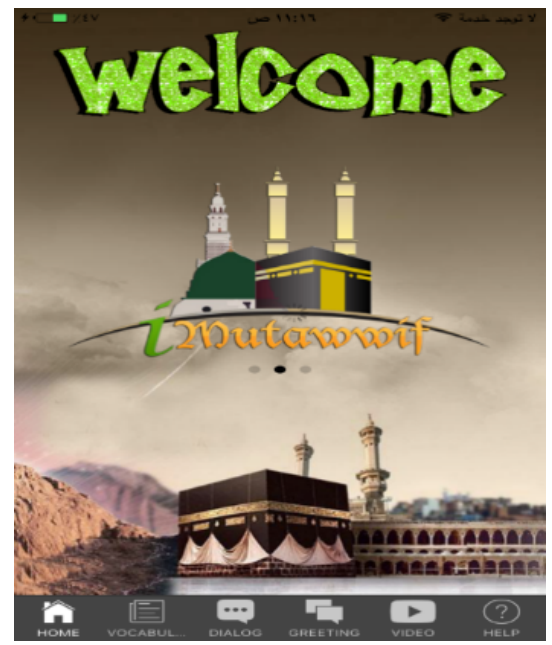

Fig. 6. Main interface or 'Home' tab for i-Mutawwif mobile application.

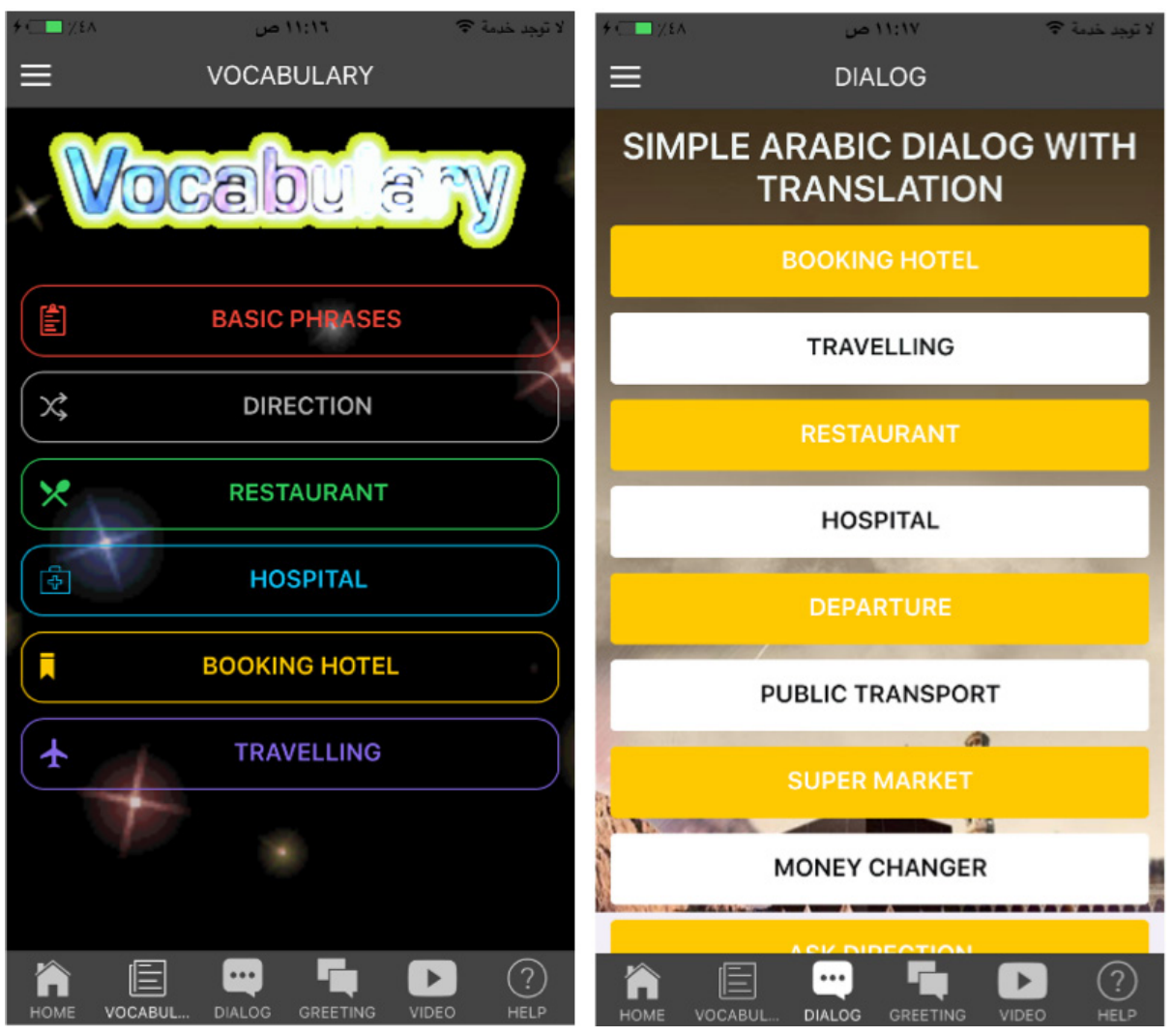

Fig. 7. Vocabulary and dialogues tabs in i-Mutawwif mobile application. 


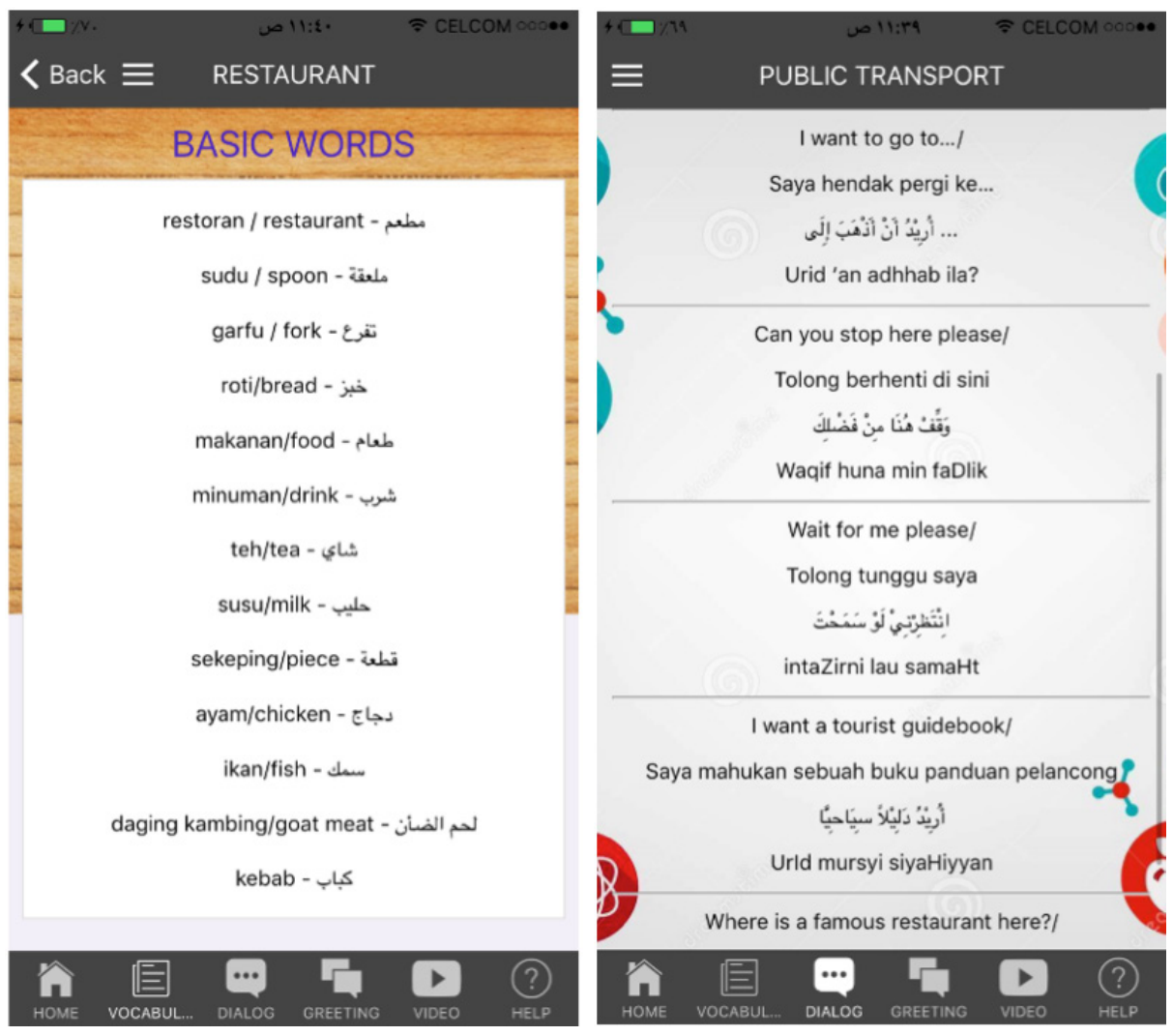

Fig. 8. Page view for Vocabulary and Dialog in i-Mutawwif mobile application.

The selection of vocabularies, phrases and sentences was done in order to assist Mutawwif to use simple phrases in Arabic language during performing Hajj and Umrah. The language contents are simple according to places and situations, enhanced with translation in both Malay and English languages and facilitated with the spelling of Arabic words and sentences in Romanize letters.

\section{Evaluation Results of i-Mutawwif}

The evaluation survey was distributed among 50 respondents who are purposively selected from 3 mutawwif and 20 learners in Baitul Mal Professional Institute under the specialization of Diploma in Hajj and Umrah Management from 26 March until 20 April 2017. The administered survey is adapted from Amani Nawi [24] and Mohd Taufik [25]. The results and findings are reported in three main categories which are demographic information, needs analysis results of the design of mobile language traveller guide in Arabic for Mutawwif (umrah tour guide) via smart phones and further suggestions by the respondents for future design and development. The details are as shown in the following: 


\subsection{Demographic Information}

As shown in Table 3, the majority of respondents are between the ages of 20-29 $(82 \%)$ while the rests are between the age of 30 and above $(10 \%)$ and missing percentage is $8 \%$.

In addition, it is very clear from Table 4 that most of the respondents are male with $88 \%$. The results show that majority of them are in their early adolescent.

Table 5 shows that the majority are still in their early experience of career as Mutawwif with $62 \%$. The results are consistent with the majority of majority of them who are in their early adolescent.

Based on Table 6, it is clear that majority of respondents are using Malay as their spoken medium of instruction with 53.5\%, followed by Arabic (26.2\%), English $(19.3 \%)$ and others (1.1\%). The results may affect the design and development of this mobile language traveller guide in Arabic for Mutawwif (umrah tour guide) via smart phones which may be using trilingual form of languages in Malay as primary language, and supported by Arabic and English for translation.

Table 3. Age of respondents

\begin{tabular}{c|c|c}
\hline Age & Frequency (N) & Percentage (\%) \\
\hline $20-29$ & 41 & 82 \\
$30-39$ & 5 & 10 \\
$40-49$ & 0 & 0 \\
Missing & 4 & 8 \\
\hline TOTAL & $\mathbf{5 0}$ & $\mathbf{1 0 0 \%}$ \\
\hline
\end{tabular}

Table 4. Gender

\begin{tabular}{c|c|c}
\hline Sex & Frequency (N) & Percentage (\%) \\
\hline Male & 35 & 71.4 \\
Female & 15 & 30.6 \\
\hline Total & $\mathbf{5 0}$ & $\mathbf{1 0 0}$ \\
\hline
\end{tabular}

Table 5. Experience as Mutawwif

\begin{tabular}{c|c|c}
\hline Years Of Experience & Frequency (N) & Percentage (\%) \\
\hline $1-5$ & 31 & 62 \\
$6-10$ & 0 & 0 \\
No Experience & 11 & 22 \\
Missing & 6 & 12 \\
\hline Total & $\mathbf{5 0}$ & $\mathbf{1 0 0}$ \\
\hline
\end{tabular}


Table 6. Spoken Language

\begin{tabular}{c|c|c}
\hline Sex & Frequency (N) & Percentage (\%) \\
\hline Malay & 49 & 98 \\
English & 26 & 52 \\
Arabic & 24 & 48 \\
Others & 1 & 2 \\
Missing & 1 & 2 \\
\hline
\end{tabular}

\subsection{Evaluation on the Features and Performance of Mobile Language Traveller Guide in Arabic for i-Mutawwif}

In general, Table 7 shows that almost all respondents are satisfied with the features and performance of this mobile app for "agree" and strong agree" from $62 \%$ to $100 \%$ which is considered as majority.

Table 7. Features and Performance of Mobile Language Traveller Guide in Arabic for iMutawwif

\begin{tabular}{|c|c|c|c|c|c|c|}
\hline No & Items & $\begin{array}{l}\text { Strongly } \\
\text { disagree }\end{array}$ & Disagree & Somewhat & Agree & $\begin{array}{l}\text { Strongly } \\
\text { Agree }\end{array}$ \\
\hline 1. & Interface design is attractive. & $\begin{array}{c}5 \\
(10 \%)\end{array}$ & $\begin{array}{c}2 \\
(4 \%)\end{array}$ & $\begin{array}{c}10 \\
(20 \%)\end{array}$ & $\begin{array}{c}11 \\
(22 \%)\end{array}$ & $\begin{array}{c}20 \\
(40 \%)\end{array}$ \\
\hline 2. & $\begin{array}{l}\text { Font of text is appropriate and } \\
\text { readable. }\end{array}$ & 0 & 0 & 0 & 0 & $\begin{array}{c}50 \\
(100 \%)\end{array}$ \\
\hline 3. & Graphic used is attractive. & 0 & 0 & 0 & 0 & $\begin{array}{c}50 \\
(100 \%)\end{array}$ \\
\hline 4. & Icon used is suitable. & 0 & 0 & 0 & 0 & $\begin{array}{c}50 \\
(100 \%)\end{array}$ \\
\hline 5. & The quality of audio is authorize. & 0 & 0 & 0 & 0 & $\begin{array}{c}50 \\
(100 \%)\end{array}$ \\
\hline 6. & $\begin{array}{l}\text { Interactive (eg: scroll over, touch } \\
\text { button, hyperlink). }\end{array}$ & 0 & 0 & 0 & $\begin{array}{c}5 \\
(10 \%)\end{array}$ & $\begin{array}{c}45 \\
(90 \%)\end{array}$ \\
\hline 7. & $\begin{array}{l}\text { User friendly (eg: easy to use the } \\
\text { application, navigation to each } \\
\text { topic, etc). }\end{array}$ & $\begin{array}{c}1 \\
(2 \%)\end{array}$ & $\begin{array}{c}2 \\
(8 \%)\end{array}$ & $\begin{array}{c}7 \\
(14 \%)\end{array}$ & $\begin{array}{c}11 \\
(22 \%)\end{array}$ & $\begin{array}{c}24 \\
(48 \%)\end{array}$ \\
\hline 8. & $\begin{array}{l}\text { Tutorial provided is easy to under- } \\
\text { stand. }\end{array}$ & $\begin{array}{c}6 \\
(12 \%)\end{array}$ & $\begin{array}{c}1 \\
(2 \%)\end{array}$ & $\begin{array}{c}6 \\
(12 \%)\end{array}$ & $\begin{array}{c}9 \\
(18 \%)\end{array}$ & $\begin{array}{c}26 \\
(52 \%)\end{array}$ \\
\hline 9. & Easy to get the information. & $\begin{array}{c}6 \\
(12 \%)\end{array}$ & $\begin{array}{c}1 \\
(2 \%)\end{array}$ & $\begin{array}{c}6 \\
(12 \%)\end{array}$ & $\begin{array}{c}11 \\
(22 \%)\end{array}$ & $\begin{array}{c}24 \\
(48 \%)\end{array}$ \\
\hline 10. & The information is well arranged. & 0 & 0 & 0 & 0 & $\begin{array}{c}50 \\
(100 \%)\end{array}$ \\
\hline 11. & The overall website is excellent. & $\begin{array}{c}4 \\
(8 \%)\end{array}$ & $\begin{array}{c}3 \\
(6 \%)\end{array}$ & $\begin{array}{c}11 \\
(22 \%)\end{array}$ & $\begin{array}{c}11 \\
(22 \%)\end{array}$ & $\begin{array}{c}21 \\
(42 \%)\end{array}$ \\
\hline
\end{tabular}




\subsection{Evaluation on the Content Delivery of Mobile Language Traveller Guide in Arabic for i-Mutawwif}

Initially, Table 8 shows that almost all respondents are satisfied with the content delivery of this mobile app for "agree" and strong agree" from $6 \%$ to $100 \%$ which is considered as majority.

Table 8. Content Delivery of Mobile Language Traveller Guide in Arabic for i-Mutawwif

\begin{tabular}{|c|c|c|c|c|c|c|}
\hline No & Items & $\begin{array}{l}\text { Strongly } \\
\text { disagree }\end{array}$ & Disagree & $\begin{array}{c}\text { Some- } \\
\text { what }\end{array}$ & Agree & $\begin{array}{c}\text { Strongly } \\
\text { Agree }\end{array}$ \\
\hline 1. & $\begin{array}{l}\text { Content of the website is related to the } \\
\text { topic. }\end{array}$ & $\begin{array}{c}5 \\
(10 \%)\end{array}$ & $\begin{array}{c}2 \\
(4 \%)\end{array}$ & $\begin{array}{c}7 \\
(14 \%)\end{array}$ & $\begin{array}{c}10 \\
(20 \%)\end{array}$ & $\begin{array}{c}26 \\
(52 \%)\end{array}$ \\
\hline 2. & Content of the website is relevant. & $\begin{array}{c}1 \\
(2 \%)\end{array}$ & 0 & $\begin{array}{c}9 \\
(18 \%)\end{array}$ & $\begin{array}{c}8 \\
(16 \%)\end{array}$ & $\begin{array}{c}27 \\
(54 \%)\end{array}$ \\
\hline 3. & $\begin{array}{l}\text { The content is arranged in an orderly } \\
\text { manner (eg: easy to hard, etc). }\end{array}$ & $\begin{array}{c}6 \\
(12 \%)\end{array}$ & $\begin{array}{c}2 \\
(4 \%)\end{array}$ & $\begin{array}{c}6 \\
(12 \%)\end{array}$ & $\begin{array}{c}14 \\
(28 \%)\end{array}$ & $\begin{array}{c}22 \\
(44 \%)\end{array}$ \\
\hline 4. & $\begin{array}{l}\text { Use simple language and easy to } \\
\text { understand. }\end{array}$ & $\begin{array}{c}5 \\
(10 \%)\end{array}$ & $\begin{array}{c}1 \\
(2 \%)\end{array}$ & $\begin{array}{c}7 \\
(14 \%)\end{array}$ & $\begin{array}{c}10 \\
(20 \%)\end{array}$ & $\begin{array}{c}27 \\
(54 \%)\end{array}$ \\
\hline 5. & $\begin{array}{l}\text { The content delivers most of the } \\
\text { information you expected to learn. }\end{array}$ & 0 & 0 & 0 & 0 & $\begin{array}{c}50 \\
(100 \%)\end{array}$ \\
\hline 6. & The examples shown are clear. & $\begin{array}{c}5 \\
(10 \%)\end{array}$ & $\begin{array}{c}2 \\
(4 \%)\end{array}$ & $\begin{array}{c}7 \\
(14 \%)\end{array}$ & $\begin{array}{c}13 \\
(26 \%)\end{array}$ & $\begin{array}{c}22 \\
(44 \%)\end{array}$ \\
\hline 7. & $\begin{array}{l}\text { Supporting materials are provided (eg: } \\
\text { exercises, activity, games, etc). }\end{array}$ & $\begin{array}{c}6 \\
(12 \%)\end{array}$ & $\begin{array}{c}3 \\
(6 \%)\end{array}$ & $\begin{array}{c}8 \\
(16 \%)\end{array}$ & $\begin{array}{c}12 \\
(24 \%)\end{array}$ & $\begin{array}{c}21 \\
(42 \%)\end{array}$ \\
\hline 8. & $\begin{array}{l}\text { Supporting materials provided are } \\
\text { adequate and various. }\end{array}$ & $\begin{array}{c}5 \\
(10 \%)\end{array}$ & $\begin{array}{c}2 \\
(4 \%)\end{array}$ & $\begin{array}{c}10 \\
(20 \%)\end{array}$ & $\begin{array}{c}11 \\
(22 \%)\end{array}$ & $\begin{array}{c}22 \\
(44 \%)\end{array}$ \\
\hline 9. & $\begin{array}{l}\text { The contents of the module helps me } \\
\text { to understand Arabic for tourism } \\
\text { purpose very well. }\end{array}$ & $\begin{array}{c}5 \\
(10 \%)\end{array}$ & $\begin{array}{c}1 \\
(2 \%)\end{array}$ & $\begin{array}{c}10 \\
(20 \%)\end{array}$ & $\begin{array}{c}12 \\
(24 \%)\end{array}$ & $\begin{array}{c}22 \\
(44 \% 0\end{array}$ \\
\hline 10. & The overall content provided is useful. & $\begin{array}{c}5 \\
(10 \%) \\
\end{array}$ & $\begin{array}{c}1 \\
(2 \%)\end{array}$ & $\begin{array}{c}7 \\
(14 \%)\end{array}$ & $\begin{array}{c}12 \\
(24 \%)\end{array}$ & $\begin{array}{c}25 \\
(50 \%)\end{array}$ \\
\hline
\end{tabular}

\subsection{Open-Ended Responses}

This paper is also gathering the responses by the respondents on the strengths, weaknesses and further suggestion for the improvement of this mobile language app such as the following:

1. Strengths: This mobile app is good, useful and supportive in helping the mutawwif to improve their Arabic language. It is also informative, well presented, easy to understand and smart app.

2. Weaknesses: Need to include more vocabularies and conversations by using bigger size of Arabic fonts.

3. Further Suggestions: The suggestions are given to include more vocabularies and conversations, enhance the graphic and colour presentations, adding search box for the vocabulary, more video and information on umrah. 


\section{Discussion of Findings}

In general, the discussion of findings in paper this can be categorized into several issues which are:

a) Features and Performance of Mobile Language Traveller Guide in Arabic for Mutawwif

b) Content Delivery of Mobile Language Traveller Guide in Arabic for Mutawwif

c) Future Improvement of Mobile Language Traveller Guide in Arabic for Mutawwif

From the results and findings, it is clear that the users are mostly satisfied with the practical use of this mobile app in Arabic for performing their duties as Mutawwif or Umrah guide traveler in Saudi Arabia. It is also satisfying the expectation of mutual Mutawwif of Arabic learners in Baitul Mal Professional Institute under the specialization of Diploma in Hajj and Umrah Management. However, this mobile app prototype has the potential to be improved and enhanced more in the future with more interesting and sophisticated multimedia and mobile elements.

\section{Conclusion}

This paper reports on the development and evaluation study of a mobile language traveller guide in Arabic for Mutawwif (umrah tour guide) via smart phones. Overall findings show positive feedback among respondents with regard to the evaluation use of this mobile language traveller guide. The respondents also have contributing their suggestions and comments in terms of further improvement of this mobile language app. This mobile app has won a silver medal in the Research and Innovation Week from 13 - 14 April 2017 organised by Sultan Zainal Abidin University (UniSZA), Terengganu, Malaysia.

\section{Acknowledgement}

The authors would like to thank the Kulliyyah of Islamic Revealed Knowledge and Human Sciences, International Islamic University Malaysia (IIUM), Kulliyyah of Education, IIUM and Research Management Centre (RMC), IIUM for their support and assistance during the period of data collection in this study. They would also like to thank the Research Management Centre for managing the grant secured for the study under RIGS, IIUM since 2015-2017.

\section{References}

[1] Colpaert, J. (2004). From courseware to coursewear? Computer Assisted Language Learning, 17, 261-266. https://doi.org/10.1080/0958822042000319575

[2] Beatty, K. (2003). Teaching and researching computer-assisted language learning. Essex, England: Pearson Education Limited. 
Paper-Development and Evaluation of i-Mutawwif: A Mobile Language Traveller Guide in Arabic ...

[3] Pachler, N., Cook, J. and Bachmair, B. (2010) Appropriation of mobile cultural resources for learning. International Journal of Mobile and Blended Learning, 2 (1). pp. 1-21. ISSN 1941-8647. https://doi.org/10.4018/jmbl.2010010101

[4] Abu Sa'alek, Atef Odeh (2014). A review of emerging technologies: Mobile assisted language learning (MALL). Asian Journal of Education and e-Learning, (ISSN: 2321 2454). Volume 02 - Issue 06, December.

[5] Attewell J and Savill-Smith C (2004). Learning with mobile devices - research and development - a book of papers. Learning Skills Development Agency: London.

[6] Turunen H, Syvaenen A, Ahonen M (2003). Supporting observation tasks in a primary school with the help of mobile devices. In K Nyvri (ed) Mobile learning: essays on philosophy, psychology and education. Communications in the 21st Century. Vienna: Passagen Verlag, 209-221.

[7] Proctor, N \& Burton, J (2003). Tate Modern multimedia tour pilots 2002-2003. Proceedings of MLEARN 2003: Learning with Mobile Devices. London, UK: LSDA, pp. 127-130

[8] Wang, M., Shen, R., Novak, D., \& Pan, X., 2009. The Impact of Mobile Learning on Students' Learning Behaviours and Performance: Report from a Large Blended Classroom. British Journal of Educational Technology, 40(4), 673-695. https://doi.org/10.1111/j.14678535.2008.00846.x

[9] Uzunboylu, H., Cavus, N., \& Ercag, E. (2009). Using mobile learning to increase environmental awareness. Computers \& Education, 52(2), 381-389. https://doi.org/10.1016/j.c ompedu.2008.09.008

[10] Al-Fahad, F. N., (2009). Students' Attitudes and Perceptions towards the Effectiveness of Mobile Learning in King Saud University, Saudi Arabia. Online Submission.

[11] Kukulska-Hulme, A., Shield, L. (2008). An overview of mobile assisted language learning: From content delivery to supported collaboration and interaction. ReCALL, 20(3), 271-289. https://doi.org/10.1017/S0958344008000335

[12] Ogata, H., Yin., C., El-Bishouty, M. M. and Yano, Y. (2010). Computer supported ubiquitous learning environment for vocabulary learning. International Journal of Learning Technology, 5 (1), 5-24. https://doi.org/10.1504/IJLT.2010.031613

[13] Huang, Y.-M., Huang, Y.-M., Huang, S.-H., Lin, Y.-T. (2012). A ubiquitous English vocabulary learning system: Evidence of active/passive attitudes vs. usefulness/ease-of-use. Computers and Education, 58, 273-282. https://doi.org/10.1016/j.compedu.2011.08.008

[14] Yamaguchi, T. (2005). Vocabulary learning with a mobile phone. Program of the 10th Anniversary Conference of Pan-Pacific Association of Applied Linguistics, Edinburgh, UK.

[15] Tayebinik, M., Puteh, M. (2012). Mobile Learning to Support Teaching English as a Second Language. Journal of Education and Practice. Vol 3, No 7, 56-62.

[16] Sumi, Y., Etani, T., Fels, S., Simone, N., Kobayashi, K., Mase, K.(1998): C-map: Building a context-aware mobile assistant for exhibition tours. The First Kyoto Meeting on Social Interaction and Communityware (June)

[17] O'Grady, M.J., O'Rafferty, R.P., O'Hare, G.M.P.(1999): A tourist-centric mechanism for interacting with the environment. In: Proceedings of the First International Workshop on Managing Interactions in Smart Environments, Dublin, Ireland, Springer (Dec) 56-67

[18] Stock, O., Zancarano, M. (2002): Intelligent interactive information presentation for cultural tourism. Invited talk at the International Workshop on Natural, Intelligent and Effective Interaction in Multimodal Dialogue Systems, Copenhagen, Denmark (June)

[19] Mohd. Feham, Md Ghalib, Haslina, Hassan, Muhammad Sabri, Sahrir, Nuraihan, Mat Daud, Mohaida, Mohin and Media Anugerah, Ayu (2014). Developing icollect mobile 
Paper-Development and Evaluation of i-Mutawwif: A Mobile Language Traveller Guide in Arabic ...

(Android and Iphone-based) application for Arabic language teaching. Middle-East Journal of Scientific Research, 20. pp. 21-27. ISSN 1990-9233 (P) 1999-8147 (O)

[20] Mohd Feham Md. Ghalib, Yushiana Mansor, Nafi@ Hanafi Dollah, Rusni Hassan, Zakaria Omar, Abdul Wahab Zakaria (2016) Providing a Mobile Service for Academics and Professionals: Need Analysis for the Development of Mobile App Glossary of Terms in Islamic Banking and Finance. In: Envisioning the Future of Online Learning. Springer, Singapore. ISBN 978-981-10-0952-5

[21] Malachowski, M.J. (2002). ADDIE based five-step method towards instructional design. An online article on Instructional Design Models website by School of Education, University of Colorado, USA.

[22] Mohd Feham Md. Ghalib, Yushiana Mansor, Nafi @ Hanafi Dollah, Rusni Hassan, Zakaria Omar, Abdul Wahab Zakaria (2016) Providing a Mobile Service for Academics and Professionals: Need Analysis for the Development of Mobile App Glossary of Terms in Islamic Banking and Finance. In: Envisioning the Future of Online Learning. Springer, Singapore. ISBN 978-981-10-0952-5

[23] Wilken, J. (2016). Ionic in action: Hybrid mobile apps with ionic and angular-js. New York: Manning Publications.

[24] Amani, Nawi (2014). Tasmim Wehdat Dirasiyyah Hasubiyyah li al-Ta'birat alIstilahiyyah fi al-Lughah al-Arabiyyah: Talabah Jami'ah al-Islamiyyah al-Alamiyyah Namuzajan. Masters Thesis, International Islamic University Malaysia, Kuala Lumpur

[25] Mohd Taufik, Abd Ghani, et. al (2016). Employing websites in language learning for tourism purpose among Arabic learners at the MARA Poly-Tech College. In: Envisioning the Future of Online Learning. Springer, Singapore. ISBN 978-981-10-0952-5, pp. 23-30

\section{Authors}

Muhammad Sabri Sahrir is with the Department of Language and Literacy, Kulliyyah of Education (KOED), International Islamic University Malaysia, 53100 Kuala Lumpur, Malaysia (muhdsabri@iium.edu.my).

Mohd Firdaus Yahaya is with the Centre of Arabic Language Studies, Faculty of Languages and Communication, Universiti Sultan Zainal Abidin, Kampus Gong Badak, 21300 Kuala Terengganu, Terengganu, Malaysia.

Taufik Ismail is with th e Department of Arabic Language and Literature, Kulliyyah Of Islamic Revealed Knowledge And Human Sciences (KIRKHS), IIUM.

Muhamad Azhar Zubir is with the Department of Arabic Language and Literature, Kulliyyah Of Islamic Revealed Knowledge And Human Sciences (KIRKHS), IIUM.

Wan Rusli Wan Ahmad is with the Department of Language and Literacy, Kulliyyah of Education (KOED), International Islamic University Malaysia, 53100 Kuala Lumpur, Malaysia.

Article submitted 15 September 2017. Final acceptance 06 March 2018. Final version published as submitted by the authors. 